\title{
Xenodiversity in a hot-spot of herpetological endemism: first records of Trachemys scripta, Ameiurus melas and Carassius auratus in a circum-Sardinian island
}

\section{Corrado Battisti}

Torre Flavia LTER (Long Term Ecological Research) Station, Città metropolitana di Roma Capitale, Servizio Aree protette, via Tiburtina, 601, 00159 Rome, Italy.

Email: c.battisti@cittametropolitanaroma.gov.it

KEYWORDS. Pet introduction, Discoglossus sardus, Hyla sarda, Sardinia.

Battisti C. 2017. Xenodiversity in a hot-spot of herpetological endemism: first records of Trachemys scripta, Ameiurus melas and Carassius auratus in a circum-Sardinian island. Belgian Journal of Zoology 147 (1): 55-60. https://doi.org/10.26496/bjz.2017.4

Introduced species can induce structural and functional changes in diversity. This xenodiversity (from the Greek: 'strange') have become a severe threat in aquatic ecosystems and is implicated both in the declines of many native amphibian species and in the change of related biogeographical patterns, especially in the islands $(1,2)$. The situation may be critical in contexts where endemic taxa are largely diffused, such as in small islands.

Sardinia is known for its notable levels of distinctive herpetological diversity with a large proportion of endemic species (3). In particular, the circum-Sardinian small islands harbour peculiar assemblages of species populations of high conservation concern (4).

During August 2016, I conducted a non-standardized biological survey in the Island of San Pietro (Sulcis archipelago, Province of Carbonia-Iglesias; South-Western Sardinia; Special Area of Conservation: code ITB040027; Fig. 1), a hot-spot for herpetological endemism at a regional level since here five Tyrrhenian species occur: two amphibians: Discoglossus sardus Tschudi, 1837 and Hyla sarda (De Betta, 1857) and three reptiles, Euleptes europaea (Gené, 1839), Algyroides fitzingeri (Wiegmann, 1834), Podarcis tiliguerta (Gmelin, 1789). In addition, local Sardinian sub-species such as Chalcides c. vittatus Leuckart, 1828 and Podarcis siculus cetti (Cara, 1871) are present (4). Regarding amphibians, I devoted particular attention to ponds and artificial reservoirs to directly or indirectly detect individuals. On the island, a limited number of irregular/seasonal streams and temporary natural or anthropogenic ponds (e.g., water tanks for agriculture and sheep/cattle grazing) are present, all highly suitable for amphibians. However, excluding the salt marshes of Carloforte, the largest wetland located on this Island is an inland artificial water reservoir in a non-urbanized context along the Northern sector (Nasca lake; coordinates: 39.1666 Lat N, 8.2571 Long E; size area 3 ha). It was built during the first half of $20^{\text {th }}$ Century as a water supply. The shores of the basin are occupied by a continuous Typha reed bed. In the surroundings, a Mediterranean maquis with Erica arborea, Pistacia lentiscus, Genista ephedroides, Juniperus turbinata and Arbutus unedo is present (Erico-Arbutetum unedonis and Oleo lentiscetumgenistetosum associations), alternating with Mediterranean open prairies (Thero-Brachipodietea). 
Inside this water reservoir, we recorded an assemblage of alien freshwater vertebrate species (one reptile and two fishes). Using replicated visual observations, a digital camera and a fishing net (to capture individuals for taxonomic diagnosis: 1-mm diameter mesh), I identified individuals of Trachemys scripta (Schoepff, 1792) (max number contemporarily observed: $\mathrm{n}=12$; one individual captured: $\max$ length: $25 \mathrm{~cm}$ ), Ameiurus melas (Rafinesque, 1820) (max $\mathrm{n}=11$, ranging between 8 and $25 \mathrm{~cm}$; one juv. captured: $8 \mathrm{~cm}$ ) and Carassius auratus (Linnaeus, 1758): $>150$ individuals showing different chromatic phenotype and counted using digital images and Photoshop software for Windows $(\mathrm{n}=10$ captured: range: $6-11 \mathrm{~cm}$ ). The presence of this non-native assemblage is known from the local people and has probably existed at least since the year 2000 (M. Masnada, pers. comm.).

Regarding Trachemys scripta, localized evidence in some urbanized areas (Olbia, Oristano, Cagliari) and inland waters (Baratz lake, Flumendosa and Tirso rivers) exists for Sardinia, but not for the circumSardinian islands (5: p. 173, 6, 7, 8, 9). The North American Ameiurus melas, introduced in Europe for aquaculture in 1871 (10) and, subsequently, into Italian freshwater ecosystems, including on large islands $(11,12)$, has a high potential to invade new areas and establish viable population $(13,14)$. From 1960, this species has been locally introduced into Northern Sardinia $(15,16,17,18,19)$. Finally, Carassius auratus, native of Central Asia, China and Japan, is relatively diffused in Sardinian lakes and ponds $(18,19)$. For all these species, these are the first records from a circum-Sardinian island. The original agent of introduction for these invasive aquatic vertebrates was probably related to ornamental purposes (pet amateurs; M. Masnada, pers. comm.), analogously to other Mediterranean sites $(20,21)$.

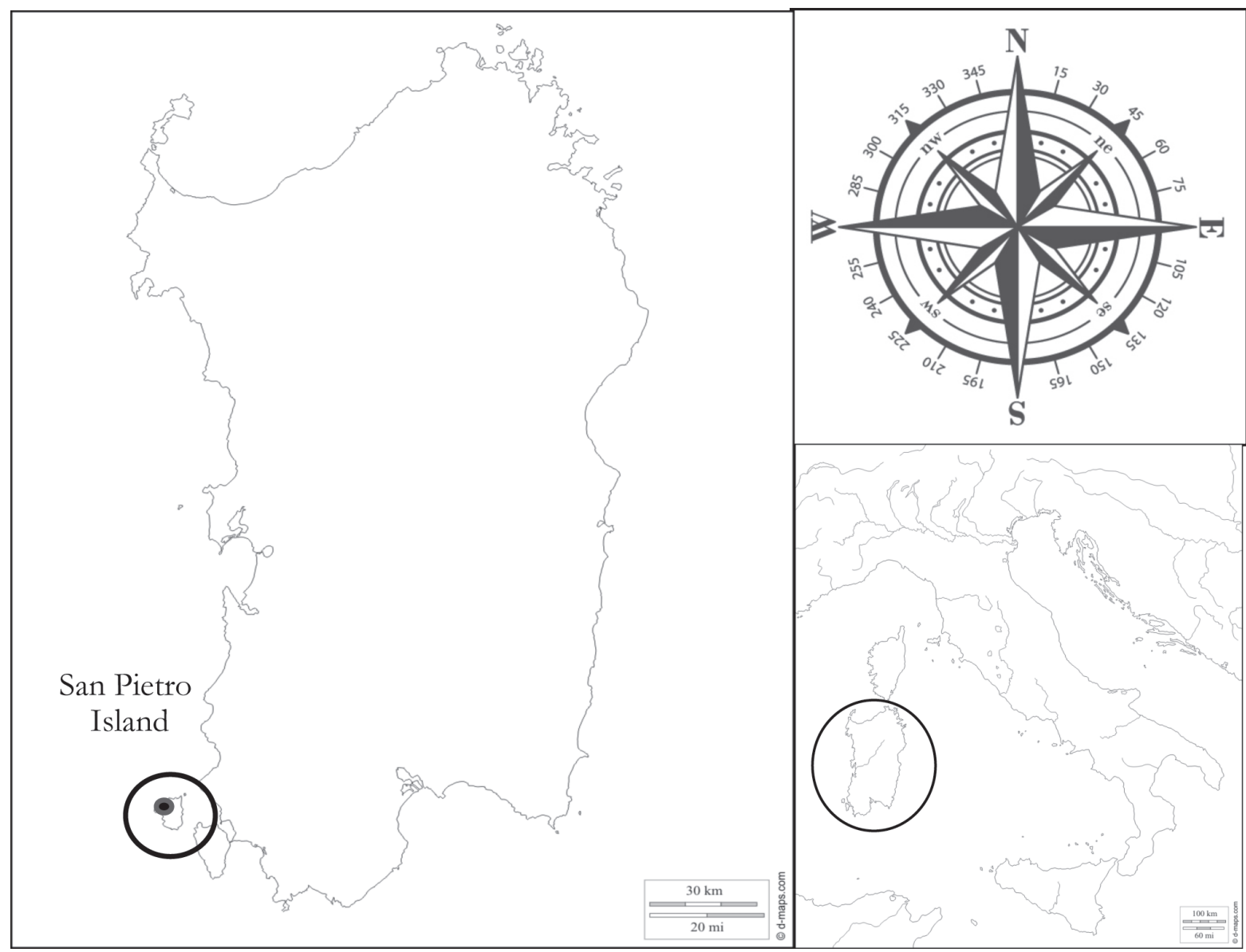

Figure 1 - Map of the study site (right side: Sardinia; left side, in the circle: Island of San Pietro; black point: the Nasca water reservoir). 
The introduction of species into an aquatic system has been shown to directly or indirectly impact aquatic fauna with complex effects, apparently depending on density of invaders, macrophyte abundance and community structure of ecosystems $(22,23,24)$. In our case, the presence of this alien xeno-assemblage may represent a potential threat for the rich endemic herpetofauna (e.g., 4, 25, 26 and pers. obs.), and, particularly, for two species of syntopic amphibians: Hyla sarda and Discoglossus sardus. Indeed, excluding single records of occurrence (e.g., 26), the distribution at local scale of these two species is unknown but probably it is highly localized.

Trachemys scripta being highly invasive and an active predator (27), has a heavy impact on fish and amphibians species, in particular on those species that lay eggs in shallow waters (28; L. Luiselli, pers. comm.). Moreover Discoglossus individuals in larval stages may be predated by the fish (5). In this context, evidence exists regarding a strong regression of this species in Sardinia (4), mainly due to the introduction of non-native fish (29), co-occurring with other causes (e.g., Chytridiomycosis: 30). Carassius auratus is generally not considered a predator, although field observations have shown a negative direct and indirect impact on some amphibian species $(31,32)$. For example, survival of eggs and tadpoles might be affected by an increase of water turbidity and a reduction of aquatic vegetation complexity due to the presence of this fish $(33,34)$. Moreover, this predator may induce abrupt changes in tadpole behaviour and size (35). Finally, C. auratus may be a vector for new parasites and diseases (22).

The presence of three alien species (one of them, Trachemys scripta, included among the most invasive alien species worldwide; 36), syntopic with two endemic amphibians in a very natural, non-urbanized insular context is cause for concern. In this sense, local governments with territorial jurisdiction (e.g., Public Agency that manage the Special Area of Conservation) should provide conservation measures (sensu 37) in order to maintain the ecological suitability of insular populations of conservation interest. More particularly, (i) species-specific removal projects (e.g., rapid response eradication actions; see 38), and (ii) education actions to prevent pet release in nature, should be developed. Moreover, these measures could be carried out with limited effort given the small size of the area and the relatively low number of people inhabiting the island (about 6,500 inhabitants; 39).

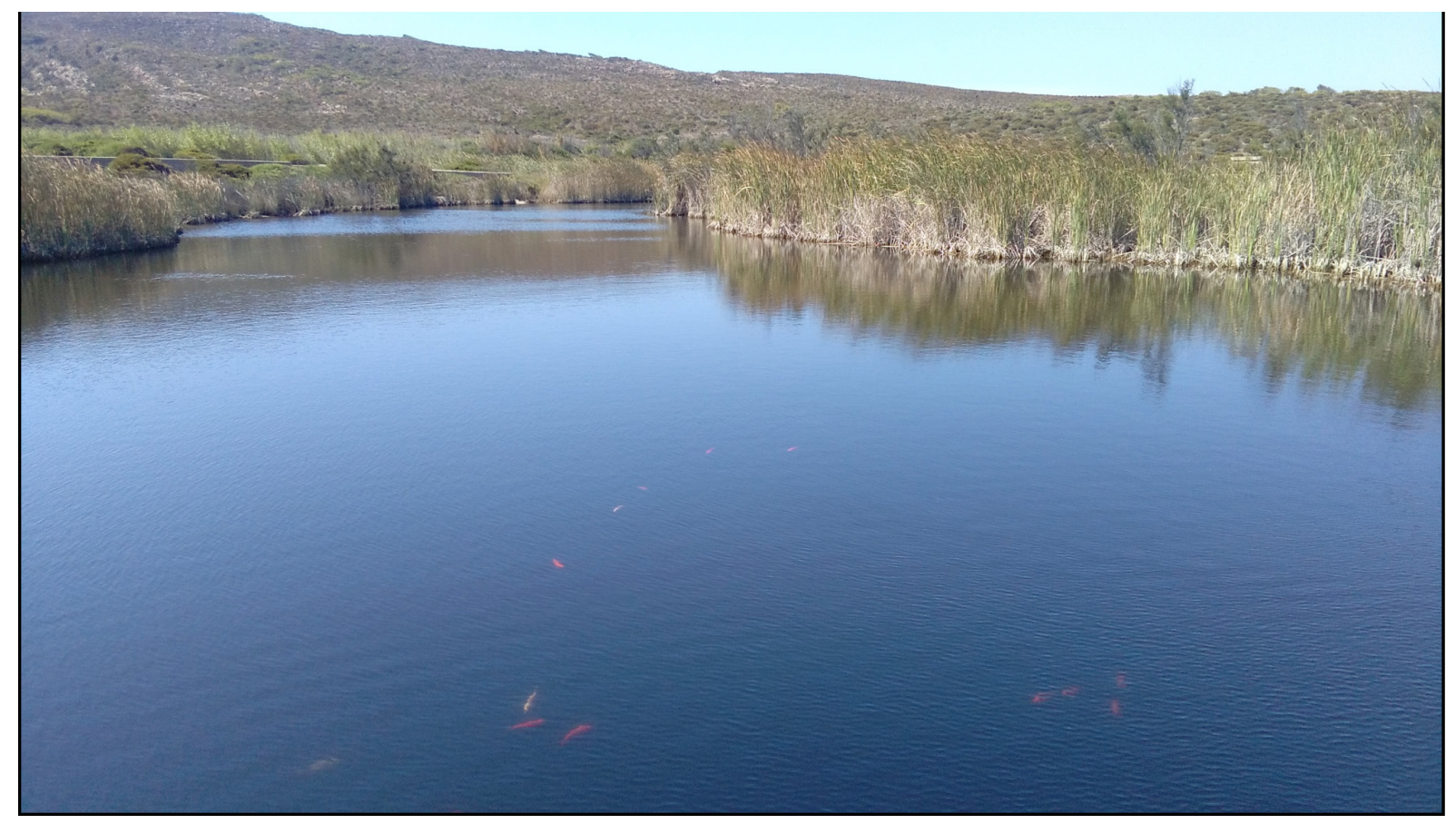

Figure 2 - The lake of Nasca (island of San Pietro, South-Western Sardinia). 


\section{Acknowledgments}

We wish to thank friends and colleagues (ecologists, ichthyologists and herpetologists) for their suggestions and comments: Marco A. Bologna, Luca Luiselli and Massimiliano Scalici (University of Rome III); Dino Biancolini (University of Rome, Sapienza); Claudia Corti and Phillip Haubrock (University of Florence); Dario Domeneghetti, Vincenzo Ferri, Lorenzo Tancioni (University of RomeTor Vergata); Pierluigi Bombi, Paolo Casula, Jean Jacques Riutort, Roberto Sindaco; M. Zapparoli (University of Tuscia, Viterbo); A. Zocchi. Thanks also to Mario Masnada who provided useful local historical information. We acknowledge also the Editors (Isa Schön, Johan Michaux, Kristiaan Hoedemakers) and two anonymous reviewers for their useful comments and suggestions that improved the first draft of this note.

\section{References}

1. Chandra S. \& Gerhardt A. (2008). Invasive species in aquatic ecosystems: issue of global concern. Aquatic Invasions 3: 1-2. https://doi.org/10.3391/ai.2008.3.1.1

2. Ficetola G.F. \& PADOA-SChiOPPA E. (2009). Human activities alter biogeographical patterns of reptiles on Mediterranean islands. Global Ecology and Biogeography 18: 214-222. https://doi. org/10.1111/j.1466-8238.2008.00433.x

3. GRILl A., CASUla P., LeCiS R. \& MenKen S. (2007). Endemism in Sardinia. In: Weiss S. \& Ferrand N. (eds) Phylogeography of Southern European Refugia: 273-296. Springer, The Netherlands.

4. Sindaco R., Doria G., Razzetti E. \& Bernini F. (2006). Atlante degli Anfibi e Rettili d'Italia. Societas Herpetologica Italica, Edizioni Polistampa, Firenze.

5. Corti C., Capula M., Luiselli L., Razzetti E. \& Sindaco R. (2011). Reptilia. Fauna d'Italia, Edizioni Calderini - Il Sole-24 Ore, Milano.

6. BASSu L., Nulchis V., SATTA M.G., Fresi C. \& CORTI C. (2008). Atlas of amphibians and reptiles of Sardinia - state of the art and general considerations. In: CORTI C. (ed.). Herpetologia Sardiniae, Latina, Societas Herpetologica/Edizioni Belvedere: 52-58.

7. Bassu L., Nulchis V., Satta M.G., Fresi C. \& Corti C. (2010). Anfibi e Rettili di Sardegna II, brevi considerazioni sulla loro distribuzione. In: Di Tizio L., Di CERBo A.R., Di FrANCESCO N. \& Cameli A. (eds) Atti VIII Congresso Nazionale Societas Herpetologica Italica, Pescara: 20-26.

8. SAlvi D. \& Bombi P. (2010). Reptiles of Sardinia: updating the knowledge on their distribution. Acta Herpetologica 5: 161-177. https://doi.org/10.13128/Acta_Herpetol-9031

9. Atzeni A., Cherchi F., Nulchis V. \& Rattu A. (2011). Censimenti della fauna nel Parco Naturale Regionale Molentargius-Saline (Sardegna). Studi Trentini Scienze Naturali 89: 19-20.

10. HoLČ́́K J. (1991). Fish Introductions in Europe with Particular Reference to its Central and Eastern Part. Canadian Journal of Fisheries and Aquatic Sciences 48 (S1): 13-23. https://doi.org/10.1139/ $\underline{991-300}$

11. Sicuro B., Tarantola M. \& Valle E. (2016). Italian aquaculture and the diffusion of alien species: costs and benefits. Aquaculture Research 47: 3718-3728. https://doi.org/10.1111/are.12997

12. Marrone F. \& NAselli-Flores L. (2015). A review on the animal xenodiversity in Sicilian inland waters (Italy). Advances in Oceanography and Limnology 6: 2-12. https://doi.org/10.4081/ aiol.2015.5451

13. Leunda P.M., Oscoz J., Elvira B., Agorreta A., Perea S. \& Miranda R. (2008). Feeding habits of the exotic black bullhead Ameiurus melas (Rafinesque) in the Iberian Peninsula: first evidence of 
BATTISTI C., Xenodiversity in a hot-spot of herpetological endemism

direct predation on native fish species. Journal of Fish Biology 73: 96-114. https://doi.org/10.1111/ j.1095-8649.2008.01908.x

14. Novomeská A. \& KovÁČ V. (2009). Life history traits of non-native black bullhead Ameiurus melas with comments on its invasive potential. Journal of Applied Ichthyology 25: 79-84. https:// doi.org/10.1111/j.1439-0426.2008.01166.x

15. Cottiglia M. (1968). La distribuzione della ittiofauna dulciacquicola in Sardegna. Rivista di Idrobiologia 7: 63-116.

16. TANCiOni L. (1992). Le specie ittiche. In: Ambienti in terra di Sardegna. Didattica ambientale per scuole medie. Regione Sardegna, Assessorato della Difesa dell'Ambiente: 194-202. Pubblicazione a cura dell'Agenzia Is Ideastudio.

17. Sтосн F. (2003). CKmap 2000. Checklist e distribuzione della fauna italiana. Available from http:// www.faunaitalia.it/ckmap/ckmap_progetto.htm (accessed 6 October 2016).

18. Zanetti M., Floris B., Turin P., Bellio M., Piccolo D., Posenato S., Bua R. \& Siligardi M. (2007). Carta ittica di $1^{\circ}$ livello dei principali bacini idrografici della Provincia di Cagliari. Amministrazione Provinciale di Cagliari, Susegana (Italy).

19. ORRÙ F., DEIANA A.M. \& CAU A. (2010). Introduction and distribution of alien freshwater fishes on the island of Sardinia (Italy). an assessment on the basis of existing data sources. Journal of Applied Ichthyology 26: 46-52. https://doi.org/10.1111/j.1439-0426.2010.01501.x

20. INNAL D. \& ERK'AKAN F. (2006). Effects of exotic and translocated fish species in the inland waters of Turkey. Reviews in Fish Biology and Fisheries 16: 39-50. https://doi.org/10.1007/s11160-006$\underline{9005-\mathrm{y}}$

21. Gherardi F., Bertolino S., Bodon M., Casellato S., Cianfanelli S., Ferraguti M., Lori E., Mura G., Nocita A., Riccardi N., Rossetti G., Rota E., Scalera R., Zerunian S. \& TRICARICO E. (2008). Animal xenodiversity in Italian inland waters: distribution, modes of arrival, and pathways. Biological Invasions 10: 435-454. https://doi.org/10.1007/s10530-007-9142-9

22. InNAL D. (2011). Distribution and impacts of Carassius species (Cyprinidae) in Turkey: a review. Management of Biological Invasions 2: 57-68.

23. KATS L.B. \& FERRER R.P. (2003). Alien predators and amphibian declines: review of two decades of science and the transition to conservation. Diversity and Distributions 9: 99-110. https://doi. org/10.1046/j.1472-4642.2003.00013.x

24. Bucciarelli G.M., Blaustein A.R., Garcia T.S. \& Kats L.B. (2014). Invasion Complexities: The Diverse Impacts of Non-native Species on Amphibians. Copeia 14: 611-632. https://doi. org/10.1643/OT-14-014

25. Bisconti R., CANeStRelli D. \& NASCETTI G. (2011). Genetic diversity and evolutionary history of the Tyrrhenian treefrog Hyla sarda (Anura: Hylidae): adding pieces to the puzzle of CorsicaSardinia biota. Biological Journal of the Linnean Society 103: 159-167. https://doi.org/10.1111/ j.1095-8312.2011.01643.x

26. De Pous P.D., Speybroeck J., Bogaerts S., Pasmans F. \& Beukema W. (2012). A contribution to the atlas of the terrestrial herpetofauna of Sardinia. Herpetology Notes 5: 391-405.

27. Ficetola G.F., Thuiller W. \& PAdOA-Schioppa E. (2009). From introduction to the establishment of alien species: bioclimatic differences between presence and reproduction localities in the slidder turtle. Diversity and Distributions 15: 108-116. https://doi.org/10.1111/j.1472-4642.2008.00516.x

28. FERRI V. \& SOCCINI C. (2003). Riproduzione di Trachemys scripta elegans in condizioni seminaturali in Lombardia (Italia settentrionale). Natura Bresciana 33: 89-92. 
29. LanZa B., Nistri A. \& VANni S. (2009). Anfibi d'Italia. Ministero dell'Ambiente e della Tutela del Territorio e del Mare, Istituto Superiore per la protezione la ricerca ambientale, Roma.

30. Bielby J., Bovero S., Sotgiu G., Tessa G., Favelli M., Angelini C., Doglio S., Clare F.C., GaZZANiga E., LAPIETRA F. \& GARNER T.W.J. (2009). Fatal Chytridiomycosis in the Tyrrhenian Painted Frog. EcoHealth 6: 27-32. https://doi.org/10.1007/s10393-009-0232-2

31. MeYer A.H., SCHMidT B.R. \& GrosSENBACHER K. (1998). Analysis of three amphibian populations with quarter-century long time-series. Proceedings of the Royal Society of London 265: 523-528.

32. Monello R.J. \& Wright R.G. (2001). Predation by goldfish (Carassius auratus) on eggs and larvae of the eastern long-toed salamander (Ambystoma macrodactylum columbianum). Journal of Herpetology 35: 350-353. https://doi.org/10.2307/1566132

33. RichARDSON M.J., WHORISKEY F.G. \& ROY L.H. (1995). Turbidity generation and biological impacts of an exotic fish Carassius auratus, introduced into shallow seasonally anoxic ponds. Journal of Fish Biology 47: 576-585. https://doi.org/10.1111/j.1095-8649.1995.tb01924.x

34. Hartel T., Nemes S., Cogălniceanu D., Öllerer K., Schweiger O., Moga C.I. \& Demeter L. (2007). The effect of fish and aquatic habitat complexity on amphibians. Hydrobiologia 583: 173-182. https://doi.org/10.1007/s10750-006-0490-8

35. Smith G.R., Burgett A.A., Temple K.G., Sparks K.A. \& Winter K.E. (2008). The ability of three species of tadpoles to differentiate among potential fish predators. Ethology 114: 701-710. https://doi.org/10.1111/j.1439-0310.2008.01505.x

36. Lowe S., Browne M., Boudjelas S. \& De Poorter M. (2000). 100 of the World's Worst Invasive Alien Species. A selection from the Global Invasive Species Database. The Invasive Species Specialist Group (ISSG) a specialist group of the Species Survival Commission (SSC) of the World Conservation Union (IUCN), 12 pp.

37. Salafsky N., Salzer D., Stattersfield A.J., Hilton-Taylor C., Neugarten R., Butchart S.H.M., Collen B., Cox N., MASTER L.L., O'ConNor S. \& Wilkie D. (2008) A standard lexicon for biodiversity conservation: unified classifications of threats and actions. Conservation Biology 22: 897-911. https://doi.org/10.1111/j.1523-1739.2008.00937.x

38. Hulme P.E. (2006). Beyond control: wider implications for the management of biological invasions. Journal of Applied Ecology 43: 835-847. https://doi.org/10.1111/j.1365-2664.2006.01227.x

39. TutT ItALIA (2016) Andamento demografico della popolazione residente nel comune di Carloforte dal 2001 al 2015. Available from http://www.tuttitalia.it/sardegna/57-carloforte/statistiche/ popolazione-andamento-demografico/ [accessed 2 February 2017]. 